Jurnal Mandala Pharmacon Indonesia, Vol 5.No.1 Juni 2019

Avaiable online at www.jurnal-pharmaconmw.com/jmpi

p-ISSN : 2442-6032

$e$-ISSN : 2598-9979

\title{
Pengaruh Tomat (Solanum lycopersicum) terhadap Diameter Tubulus Seminiferus Tikus Putih (Rattus norvegicus) Galur Sprague dawley yang Diinduksi Gentamisin
}

Fahmi Ikhtiar

Program Studi Pendidikan Dokter, Universitas Lampung

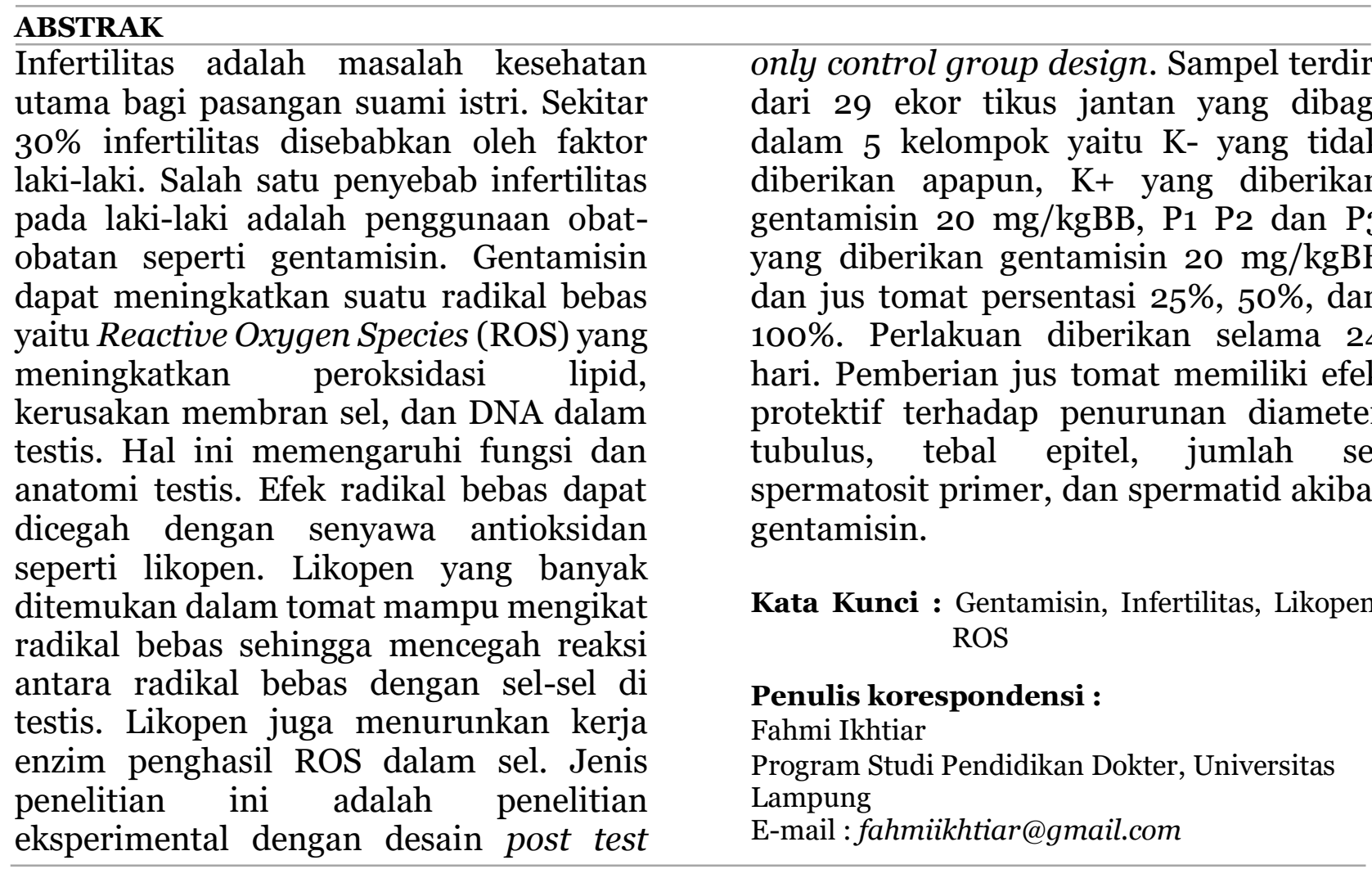

\section{PENDAHULUAN}

Infertilitas adalah pasangan yang telah aktif dan rutin berhubungan seksual selama satu tahun tanpa kontrasepsi, namun belum ada tanda-tanda kehamilan (World Health Organization, 2012). Infertilitas menjadi masalah kesehatan utama bagi pasangan suami istri dan 30\% kasus ini disebabkan oleh faktor laki-laki yang bisa disebabkan karena penggunaan obat, kemoterapi, toksin, dan faktor lingkungan yang dapat memperburuk spermatogenesis dan produksi sperma (Khaki et al., 2009).
Obat-obatan menjadi salah satu penyebab infertilitas pada pria. Contoh antibiotik yang menyebabkan infertilitas adalah golongan aminoglikosida seperti gentamisin dan neomisin. Efek samping obat ini dapat memengaruhi struktur dan fungsi testis (Olayemi, 2010). Berdasarkan penelitian yang dilakukan Narayana, pemberian gentamisin selama 35 hari dengan dosis $5 \mathrm{mg} / \mathrm{kgBB}$ pada tikus terjadi penurunan diameter tubulus seminiferus dan tebal epitel seminiferus (Narayana, 2008). 
Gentamisin dapat meningkatkan jumlah Reactive Oxygen Species (ROS) dalam testis. (El-maddawy, 2014). ROS adalah salah satu radikal bebas yang memicu peroksidasi lipid dalam testis (Kim et al., 2014). Jaringan testis dan membran sel sperma kaya akan polyunsaturated fatty acid (PUFA) yang berfungsi sebagai penyedia struktur dan kekentalan yang dibutuhkan sperma untuk kapasitasi. Tingkat ROS yang tinggi dapat merusak jaringan testis dan membran sel sperma (Aly and Hassan, 2018).

ROS menyebabkan kondisi stres oksidatif dalam testis. Stres oksidatif dapat menghambat sekresi hormon Luitenizing Hormon (LH) dan akhirnya mengurangi sintesis hormon testosteron (Al-Damegh, 2014). Menurunnya kadar testosteron dan LH menyebabkan atropi tubulus seminiferus (Eboetse Yama et al., 2011).

ROS dapat dinetralkan menggunakan antioksidan (Nouri et al., 2009). Banyak antioksidan yang dapat melindungi tubuh dari radikal bebas seperti polifenol, tokoferol, vitamin C, dan karotenoid. Salah satu karotenoid adalah likopen yang ada dalam buah tomat. Likopen dapat menurunkan risiko kanker paru-paru, payudara dan prostat. Berdasarkan penelitian yang dilakukan Jeong, likopen menurunkan jumlah ROS di mitokondria dan intraselular sel (Jeong, Lim and Kim, 2019).

Dari latar belakang tersebut, peneliti ingin mengenai pengaruh tomat (Solanum lycopersicum) terhadap diameter tubulus seminiferus tikus putih yang diinduksi gentamisin.

\section{METODE PENELITIAN}

Penelitian ini adalah penelitian eksperimental dengan desain Post test only control group design. Penelitian dilakukan di Animal House Fakultas
Kedokteran Universitas Lampung selama 24 hari. Populasi penelitian ini adalah 25 ekor tikus putih jantan (Rattus norvegicus) galur Sprague dawley yang didapat dari Institut Penelitian Bogor. Bahan penelitian yang digunakan ada dua yaitu jus tomat dosis $1 \mathrm{ml}$ dengan masing masing persentasi 100\% (tanpa pengenceran), $50 \%$ (pengenceran setengah), dan 25\% (pengenceran seperempat). Persentasi jus tomat 100\% mengandung sekitar 4,5 mg likopen didalamnya. Selain itu digunakan gentamisin dengan dosis $20 \mathrm{mg} / \mathrm{kgBB}$.

Sampel penelitian sebanyak 25 ekor dipilih secara acak dan dibagi kedalam lima kelompok dengan pengulangan sebanyak 5 kali. Kelompok kontrol negatif (K(-)) sebagai kontrol normal yang tidak diberikan gentamisin dan tomat. Kelompok kontrol positif $(\mathrm{K}(+))$ adalah kontrol patologis yang diberi gentamisin $20 \mathrm{mg} / \mathrm{kgBB}$. Kelompok perlakuan satu (P1) adalah kelompok perlakuan dengan pemberian gentamisin $20 \mathrm{mg} / \mathrm{kgBB}$ dan jus tomat persentasi 25\%. Kelompok perlakuan dua (P2) adalah kelompok perlakuan dengan pemberian gentamisin $20 \mathrm{mg} / \mathrm{kgBB}$ dan jus tomat persentasi 50\%. Kelompok perlakuan tiga $\left(\mathrm{P}_{3}\right)$ adalah kelompok perlakuan dengan pemberian gentamisin $20 \mathrm{mg} / \mathrm{kgBB}$ dan jus tomat persentasi $100 \%$.

Kelompok $\mathrm{K}(+), \mathrm{P}_{1}, \mathrm{P}_{2}$, dan $\mathrm{P}_{3}$ diberikan gentamisin $20 \mathrm{mg} / \mathrm{kgBB}$ secara bergantian. Setelah dua jam, Kelompok $\mathrm{P}_{1}, \mathrm{P}_{2}$, dan $\mathrm{P}_{3}$ diberikan jus tomat dosis 1 ml dengan persentasi 25\%, 50\%, dan 100\%. gentamisin diberikan selama 10 hari dan jus tomat diberikan selama 24 hari. Semua tikus tetap diberi makan dan minum ad libitum. Setelah perlakuan, mencit dikorbankan untuk diambil testisnya. Testis difiksasi dengan formalin 10\% dan dibuat sediaan mikroskopis dengan metode parafin dan pewarnaan 
Haematoksilin Eosin. Selanjutnya sediaan diperiksa dibawah mikroskop cahaya.

Analisis data dilakukan terhadap diameter tubulus seminiferus secara statistik. Pertama dilakukan uji normalitas dengan menggunakan uji Shapiro Wilk dan uji homogenitas Levene (Dahlan, 2014). Hasil uji menunjukkan data normal dan homogen, selanjutnya dilakukan uji parametrik One Way Annova dan dilanjutkan uji Post Hoc.

\section{HASIL DAN PEMBAHASAN}

Hasil penelitian berupa preparat dilihat dibawah mikroskop cahaya dengan perbesaran 200 kali. Diambil tiga tubulus seminiferus yang dianggap bulat setiap preparat, selanjutnya dihitung rataratanya. Diameter tubulus diukur dengan mengukur jarak terpanjang dan terpendek dari tubulus seminiferus.
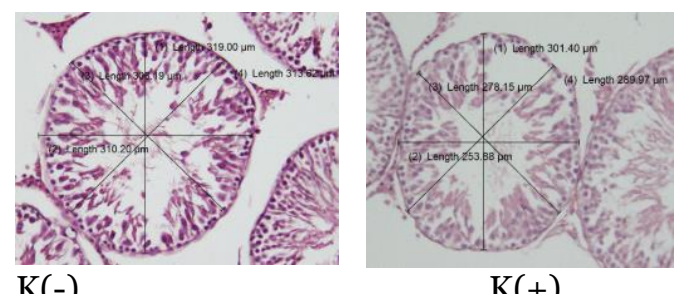

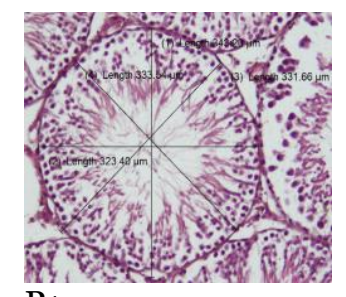

P1

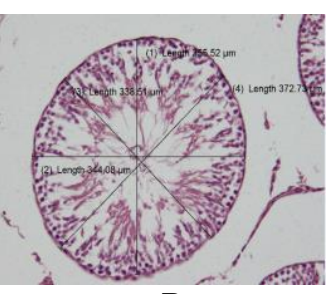

$\mathrm{P} 2$

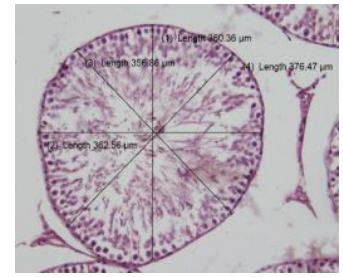

$\mathrm{P} 3$

Gambar 1. Diameter Tubulus Seminiferus

Hasil penelitian menunjukkan diameter tubulus seminiferus berkurang karena pemberian gentamisin. Hal tersebut terlihat pada kelompok $\mathrm{K}(+)$ yang memiliki diameter tubulus lebih kecil dari $\mathrm{K}(-)$ yang tidak diberikan gentamisin. Selanjutnya terjadi peningkatan diameter tubulus secara bertahap dari P1, P2, dan P3

Setelah dihitung rata-rata diameter tubulus seminiferus tiap kelompok perlakuan, dilakukan uji normalitas dan homogenitas dan didapatkan data terdistribusi normal dan homogeny (p>0,005). Selanjutnya dilakukan uji parametrik One Way Annova dan didapat

Tabel 1. Rerata Jumlah Diameter Tubulus tiap Kelompok

\begin{tabular}{cccccc}
\hline Ulangan ke & \multicolumn{5}{c}{ Kelompok Perlakuan } \\
\cline { 2 - 6 } & K(-) & K(+) & P1 & P2 & P3 \\
\hline $\mathbf{1}$ & 343,5 & 334,2 & 319,7 & 343,1 & 376 \\
$\mathbf{2}$ & 325,8 & 217,3 & 327,7 & 333,9 & 367,9 \\
$\mathbf{3}$ & 305,9 & 279,5 & 319,6 & 352,1 & 377,9 \\
$\mathbf{4}$ & 311,6 & 280,8 & 352,2 & 388,6 & 377,6 \\
$\mathbf{5}$ & 282,1 & 296,8 & 330,9 & 343,5 & 369,5 \\
Rerata \pm SD & $313,9 \pm 23,1$ & $281,7 \pm 42,2$ & $330 \pm 13,3$ & $352,2 \pm 21,3$ & $373,7 \pm 4,7$ \\
\hline
\end{tabular}

hasil $\mathrm{p}<0,005$ sehingga didapat perbedaan bermakna besar diameter tubulus seminiferus pada setiap kelompok perlakuan. Selanjutnya dilakukan analisis Post Hoc LSD untuk melihat perbedaan setiap kelompok. Tabel 2 menunjukkan ada perbedaan signifikan ukuran diameter tubulus seminiferus dari kelompok $\mathrm{K}(+)$ dengan kelompok lain. Hal ini sesuai dengan penelitian Narayana dan Khaki bahwa gentamisin dapat mengurangi diameter testis (Narayana, 2008; Khaki, 2015). Besar diameter kelompok K(-), P1, $\mathrm{P}_{2}$, dan $\mathrm{P}_{3}$ lebih besar dari kelompok $\mathrm{K}(+)$.

Mengecilnya ukuran diameter tubulus seminiferus terjadi karena efek radikal bebas dari gentamisin yang 
menyebabkan penurunan jumlah sel leydig akibat peroksidase lipid dan spermatogenesis terhambat. Spermatogenesis yang terhambat mengakibatkan penurunan jumlah sel dalam tubulus sehingga ketebalan tubulus seminiferus berkurang (Gurmeet et al., 2014). Berdasarkan penelitian Yama, diameter tubulus mengecil karena penghambatan hormon testosteron dan FSH akibat dari radikal bebas. Hal ini yang diduga sebagai penyebab atropi-atropi tubulus seminiferus.(Eboetse Yama et al., 2011).

Dari hasil uji post hoc LSD, terdapat peningkatan diameter tubulus seminiferus dari kelompok perlakuan $\mathrm{P}_{1}$,
P2, dan $\mathrm{P}_{3}$. Pemberian tomat sebagai antioksidan dapat mengurangi efek radikal bebas dari gentamisin. Likopen dalam tomat dapat menghambat enzim penghasil ROS dalam sel dan merangsang produksi enzim antioksidan dalam sel yang melindungi sel dari ROS (Palozza et al., 2011).

Walaupun terjadi peningkatan ukuran diameter tubulus, kelompok P2 dan $\mathrm{P}_{3}$ tidak signifikan ( $\mathrm{p}>0,005$ ). Hasil analisis data yang tidak signifikan ini mungkin bisa disebabkan oleh berbagai hal seperti dosis yang tidak sesuai, waktu penelitian yang singkat, dan kesalahan pemberian jus tomat dan gentamisin.

Tabel 2. Hasil uji Post Hoc LSD

\begin{tabular}{cccccc}
\multicolumn{7}{l}{ Tabel 2. Hasil uji Post Hoc LSD } \\
\hline Kelompok Perlakuan & K(-) & K(+) & P1 & P2 & P3 \\
\hline K (-) & - & $0,05^{*}$ & 0,310 & $0,022^{*}$ & $0,001^{*}$ \\
K (+) & $0,05^{*}$ & - & $0,005^{*}$ & $0,000^{*}$ & $0,000^{*}$ \\
P1 & 0,310 & $0,005^{*}$ & - & 0,165 & $0,010^{*}$ \\
P2 & $0,022^{*}$ & $0,000^{*}$ & 0,165 & - & 0,178 \\
P3 & $0,001^{*}$ & $0,000^{*}$ & $0,010^{*}$ & 0,178 & -
\end{tabular}

Keterangan : * Jika $p<0,05=$ terdapat perbedaan yang signifikan

Dosis gentamisin yang digunakan sudah sesuai karena menurut Narayana, dosis gentamisin $3 \mathrm{mg} / \mathrm{kgBB}$ dan 5 $\mathrm{mg} / \mathrm{kgBB}$ intra peritoneal (IP) sudah memberikan efek stres oksidatif terhadap diameter testis (Narayana, 2008). Lebih lanjut penelitian Khaki didapatkan kerusakan testis dengan dosis yang sama yaitu $5 \mathrm{mg} / \mathrm{kgBB}$ (Khaki et al., 2009). Dosis jus tomat juga bukan menjadi penyebab karena dari penelitian Suciati, dosis tomat $1 \mathrm{mg} / \mathrm{kgBB}$ sudah memberikan efek protektif (Suciati, Ismono and Iwan, 2012).

Rute pemberian yang digunakan dalam penelitian ini adalah peroral untuk jus tomat dan intraperitoneal untuk gentamisin. Pemberian jus tomat secara peroral sudah sesuai karena berdasarkan Research Guidline for Evaluating the Safety and Efficacy of Herbal Medicine pemberian obat yang paling tepat diberikan pada hewan uji adalah melewati rute peroral (World Health Organization, 2012). Pemberian obat gentamisin secara intraperitoneal juga tindakan yang benar karena selain peneliti banyak yang menggunakan metode tersebut, absorbsi obat melewati IP lebih banyak dibanding melewati intraperitoneal (Susianti, 2013). Kemungkinan kesalahan dari pemberian obat ketika melakukan penyuntikan gentamisin dan pencekokkan jus tomat.

\section{KESIMPULAN}

Kesimpulan hasil penelitian ini adalah terdapat pengaruh jus tomat terhadap diameter tubulus seminiferus tikus putih (Rattus norvegicus) yang diinduksi gentamisin.

\section{DAFTAR PUSTKA}

Al-Damegh, M.A. 2014. Stress-Induced Changes in Testosterone Secretion in Male Rats: Role of Oxidative Stress and 
Modulation by Antioxidants Open Journal of Animal Sciences 04(02):7078.

Aly, H. A. A. and Hassan, M. H. 2018. 'Potential testicular toxicity of gentamicin in adult rats. Biochemical and Biophysical Research Communications. Elsevier Inc 497(1): 362-367.

Dahlan, S.2014.Statistik Untuk Kedokteran Dan Kesehatan. 6th edn. Jakarta: Salemba Medika.

Eboetse Yama, O. et al. 2011. Sperm quotient in Sprague-Dawley rats fed graded doses of seed extract of Momordica charantia. Middle East Fertility Society Journal. Middle East Fertility Society 16(2): 154158.

El-maddawy, Z. K. 2014. Modulation of Gentamicin-induced Testicular and Brain Damage in Rats. 8(3): 284-293.

Gurmeet, K. S. S. et al. 2014. Detrimental effects of bisphenol a on development and functions of the male reproductive system in experimental rats. EXCLI Journal 13:. 151-160.

Jeong, Y., Lim, J. W. and Kim, H. 2019. Lycopene inhibits reactive oxygen species-mediated nf-kb signaling and induces apoptosis in pancreatic cancer cells. Nutrients 11(4).

Khaki, A. et al. 2009. Ultra structural study of gentamicin and ofloxacin effect on testis tissue in rats: Light and transmission electron microscopy. Journal of Pharmacy and Pharmacology 3(4): 105109.

Khaki, A. 2015. Assessment on the adverse effects of aminoglycosides and flouroquinolone on sperm parameters and male reproductive tissue: $\mathrm{A}$ systematic review. Iranian Journal of Reproductive Medicine 13(3): 125-134.

Kim, S. H. et al. 2014. Melatonin prevents gentamicin-induced testicular toxicity and oxidative stress in rats. Andrologia 46(9): 1032-1040.

Narayana, K. 2008. An aminoglycoside antibiotic gentamycin induces oxidative stress, reduces antioxidant reserve and impairs spermatogenesis in rats. The
Journal of toxicological sciences 33(1): 85-96.

Nouri, M. et al. 2009. The protective effects of carrot seed extract on spermatogenesis and cauda epididymal sperm reserves in gentamicin treated rats. Yakhteh 11(3): 327-333.

Olayemi, F. O. 2010. A review on some causes of male infertility. African Journal of Biotechnology 9(20): 2834-2842.

Palozza, P. et al. 2011. Role of Lycopene in the Control of ROS-Mediated Cell Growth: Implications in Cancer Prevention. Current Medicinal Chemistry 18(12): 1846-1860.

Suciati, T., Ismono, D. and Iwan, J. 2012. Pengaruh Likopen Terhadap Gambaran Tubulus Seminiferus dan Kualitas Sperma Mencit (Mus Musculus L) yang Terpapar Asap Rokok. Universitas Sriwijaya.

Susianti. 2013. Pengaruh Ekstrak Jintan Hitam ( Nigella Sativa L .) terhadap Gambaran Histopatologi Hepar , Paru , dan Testis Tikus Putih ( Rattus Norvegicus ) yang Diinduksi Gentamisin. Jurnal Sainsmat II(2): 107-118.

World Health Organization. 2012. The Pursuit of Responsible Use of Medicines: Sharing and Learning from Country Experiences. Available at: https://www.who.int/medicines/public ations/responsible_use/en/.

World Health Organization (2012) Meeting to develop a global consensus on preconception care to reduce maternal and childhood mortality and morbidity WHO Headquarters, Geneva Meeting report. Geneva: 78 . Available at: http://scholar.google.com/scholar?hl= en\&btnG=Search\&q=intitle:Meeting+to + Develop $+\mathrm{a}+$ Global+Consensus + on $+\mathrm{P}$ reconception+Care+to+Reduce+Mater nal+and+Childhood + Mortality + and $+M$ orbidity\#0\%5Cnhttp://scholar.google 